\title{
February 2015 Pulmonary Case of the Month: Severe Asthma
}

\author{
Suresh Uppalapu, MD \\ Sunil Santhanakrishnan, MD \\ Rajeev Saggar, MD
}

Banner Good Samaritan Medical Center

Phoenix, AZ

\section{History of Present IIIness}

A 50-year-old African-American woman with a history of asthma presented to the emergency department with a chief complaint of shortness of breath for 2 weeks. She reported some chest tightness, wheezing and dry cough. She denied fever, chills, myalgias or arthralgias at the time of admission.

\section{$\mathrm{PMH}, \mathrm{SH}$ and $\mathrm{FH}$}

In addition to asthma, she has a past medical history of type 2 diabetes mellitus, hypertension, and multiple sclerosis. She admitted to social smoking but states she quit 6 to 7 months ago. She denies alcohol, recreational drug use, or a family history of early coronary artery disease, strokes or cancers.

\section{Medications}

- Montelukast $10 \mathrm{mg}$ daily

- Salmeterol/fluticasone 250/50 inhaled twice a day

- Albuterol inhaler as needed for shortness of breath

- Metformin $500 \mathrm{mg}$ bid.

- Dimethyl fumarate $240 \mathrm{mg}$ bid.

- Omega 3 fish oil.

- Calcium carbonate $600 \mathrm{mg}$ daily

- Naproxen 500 mg BID

- Lisinopril 10 mg daily

- Hydrochlorothiazide $25 \mathrm{mg}$ daily.

\section{Physical Exam}

Vitals: Temperature $37.2^{\circ} \mathrm{C}$, respiratory rate 33 breaths/min, heart rate 112 beats $/ \mathrm{min}$, blood pressure $152 / 80 \mathrm{~mm} \mathrm{Hg}, \mathrm{SpO} 280 \%$ on room air but $98 \%$ on 3 liters/min by nasal cannula.

General: Mild respiratory distress.

Lungs: Diminished breath sounds diffusely with mild wheezing.

The rest of her exam was within normal limits. 


\section{Laboratory/EKG/Chest Radiography}

White blood cells $8.1 \times 10^{3}$ cells/microliter, hemoglobin $13.9 \mathrm{~g} / \mathrm{dL}$, hematocrit 41.7 , platelets 289,000 cells/microliter.

Electrolytes blood urea nitrogen, creatinine, glucose, troponin, and brain naturetic peptide were within normal limits

EKG showed sinus tachycardia but was otherwise normal.

Chest X-ray was interpreted as normal.

A thoracic CT scan showed wispy infiltrates but no evidence of pulmonary embolism or other abnormalities.

Which of the following is appropriate management at this time?

1. Bronchodilators

2. Discharge the patient to home

3. Intravenous corticosteroids

4. 1 and 3

5. All of the above 


\section{Correct!}

\section{1 and 3}

The basic principles of care for an acute exacerbation of asthma are the following (1):

- Assess the severity of the attack

- Use inhaled short-acting beta agonists early and frequently and consider concomitant use of ipratropium for severe exacerbations

- Start systemic glucocorticoids if there is not an immediate and marked response to the inhaled short-acting beta agonists

- Make frequent (every one to two hours) objective assessments of the response to therapy until definite, sustained improvement is documented

- Admit patients who do not respond well after four to six hours to a setting of high surveillance and care

- Educate patients about the principles of self-management for early recognition and treatment of a recurrent attack and develop an "asthma action plan" for recurrent symptoms

The patient was admitted to a general medical ward but did not do well. Non-invasive positive pressure ventilation (NIPPV) was considered but was not given due to clinical deterioration warranting ICU transfer for initiation of mechanical ventilation. Her initial ventilator settings were: assist/control 18, PEEP 0, FiO2 60\%, tidal volume $350 \mathrm{ml}$. She had peak respiratory pressures of about $51 \mathrm{~cm} \mathrm{H}_{2} \mathrm{O}$. Her arterial blood gases showed pH 7.15, PaCO2 $81 \mathrm{~mm} \mathrm{Hg}$, and PaO2 $114 \mathrm{~mm} \mathrm{Hg}$.

Which of the following should be considered at this time?

1. Begin oseltamivir, zanamivir, or peramivir

2. General anesthesia

3. Switch to pressure controlled ventilation

4. 1 and 3

5. All of the above 


\section{Correct! \\ 5. All of the above}

The principles of mechanical ventilation in asthma are (2):

- Avoid further dynamic hyperinflation.

- Reduce auto PEEP

- Enough sedation and consider neuromuscular blockade

- Allow permissive hypercapnia

Pressure controlled ventilation is the preferred mode of mechanical ventilation with a tidal volume of 6-8 $\mathrm{ml} / \mathrm{kg}$, a respiratory rate of $10-14$ breaths $/ \mathrm{min}$, PEEP of $0-5 \mathrm{~cm} \mathrm{H}_{2} \mathrm{O}$, with a plateau pressure of $<30 \mathrm{~cm} \mathrm{H}_{2} \mathrm{O}$.

At this time the Centers for Disease Control is recommending oseltamivir, zanamivir, or peramivir for patients suspected of potentially having influenza (3). Our patient eventually proved to be influenza A + and was treated with oseltamivir for 5 days.

The patient underwent a trial of general anesthesia with isoflurane $(4,5)$. Unfortunately, this made little difference. The arterial blood gases remained poor with a pH 7.09, pCO2 $109 \mathrm{~mm} \mathrm{Hg}$, and pO2 $113 \mathrm{~mm} \mathrm{Hg}$ on 60\% FiO2.

What additional therapies could be attempted for severe asthma?

1. Extracorporeal membrane oxygenation (ECMO)

2. Heliox

3. Ketamine

4. 1 and 3

5. All of the above 


\section{Correct! \\ 5. All of the above}

Ketamine IV anesthesia has also been tried for severe asthma with some success (6). Heliox, a mixture of helium and oxygen, is less dense than air which is predominately nitrogen and oxygen. Because it is less dense, heliox lowers upper airway resistance and has also been successfully used in severe asthma (7). Similarly, successes have also been reported with ECMO (8-10).

In our patient, a trial of ECMO resulted in improvement in her arterial blood gases to $\mathrm{pH}$ $7.475, \mathrm{pCO} 2$ of $33 \mathrm{~mm} \mathrm{Hg}$, and pO2 of $508 \mathrm{~mm} \mathrm{Hg}$ on a FiO2 of $100 \%$ within 4 hours of initiation. She slowly improved, was extubated and eventually discharged to home.

No rescue therapy has been proven to be superior to another and there are no controlled trials comparing therapies. Early ECMO may be life-saving although when to initiate ECMO has not been standardized yet.

\section{References}

1. Fanta $\mathrm{CH}$. Treatment of acute exacerbations of asthma in adults. UpToDate. June, 2010. Available at: http://nihlibrary.ors.nih.gov/jw/POC/Uaea.htm (accessed 1/25/15).

2. Shapiro JM. Management of respiratory failure in status asthmaticus. Am J Respir Med. 2002;1(6):409-16. [CrossRef] [PubMed]

3. Centers for Disease Control. Influenza antiviral medications: summary for clinicians. Available at: http://www.cdc.gov/flu/professionals/antivirals/summary-clinicians.htm (accessed 1/25/15).

4. Saulnier FF, Durocher AV, Deturck RA, Lefèbvre MC, Wattel FE. Respiratory and hemodynamic effects of halothane in status asthmaticus. Intensive Care Med. 1990;16(2):104-7. [CrossRef] [PubMed]

5. Johnston RG, Noseworthy TW, Friesen EG, Yule HA, Shustack A. Isoflurane therapy for status asthmaticus in children and adults. Chest. 1990;97(3):698-701. [CrossRef] [PubMed]

6. Hemming A, MacKenzie I, Finfer S. Response to ketamine in status asthmaticus resistant to maximal medical treatment. Thorax. 1994;49(1):90-1. [CrossRef] [PubMed]

7. Gluck EH, Onorato DJ, Castriotta R. Helium-oxygen mixtures in intubated patients with status asthmaticus and respiratory acidosis. Chest. 1990;98(3):693-8. [CrossRef] [PubMed]

8. Shapiro MB, Kleaveland AC, Bartlett RH. Extracorporeal life support for status asthmaticus. Chest. 1993;103(6):1651-4. [CrossRef] [PubMed]

9. Kukita I, Okamoto K, Sato T, Shibata Y, Taki K, Kurose M, Terasaki H, Kohrogi H, Ando M. Emergency extracorporeal life support for patients with near-fatal status asthmaticus. Am J Emerg Med. 1997;15(6):566-9. [CrossRef] [PubMed] 
10. Mikkelsen ME, Woo YJ, Sager JS, Fuchs BD, Christie JD. Outcomes using extracorporeal life support for adult respiratory failure due to status asthmaticus. ASAIO J. 2009;55(1):47-52. [CrossRef] [PubMed] 